\title{
Mating type specific chromosome conformation in Saccharomyces cerevisiae
}

\author{
Jon-Matthew Belton ${ }^{1 *}$, Davide Bau², Imen Lassardi ${ }^{3}$, Kerstin Bystricky ${ }^{3}$, Marc Marti-Renom², Job Dekker ${ }^{1}$ \\ From Epigenetics and Chromatin: Interactions and processes \\ Boston, MA, USA. 11-13 March 2013
}

Budding yeast switch their mating type by a gene conversion event at the MAT locus which uses either of two silent loci (HML or HMR) on opposite ends of chromosome three as a template. In MATa cells the left arm of Chr. Ill is "activated" which allows for the preferential recombination of $H M L$ with the MAT locus. The left arm is otherwise "repressed" for recombination in MAT $\alpha$ cells which then prefer to use $H M R$, on the right arm, as a template for gene conversion. We set out to analyze the potential role of chromosome conformation in this "activation"/"repression" phenomenon observed on the left arm of Chr. III. We used Chromosome Conformation Capture Carbon Copy (5C) to comprehensively analyze the conformation of chromosomes III, V, and XII in the two mating types. Our data reveals that the yeast genome is organized in a unique way compared to other species. We have found that global nuclearorganization such ascentromereclustering, telomere tethering to the periphery, and sequestration of the rDNA array into the nucleolus affect both the specific conformations of each chromosome but also the interactions between these chromosomes. Our analysis indicates that the overall architecture for these 3 chromosomes is very similar between the two mating types. Interestingly, a mating type specific difference in conformation of the left arm of Chr. Ill was identified. Furthermore, the $5 \mathrm{C}$ data was used, in conjunction with the Integrative Modeling Platform (IMP), to generate three dimensional models of Chr. III in both mating types. This method provides a more intuitive way of viewing $5 \mathrm{C}$ data and reveals that, in general, Chr. Ill has a more crumpled conformation in MATa cells than in $M A T \alpha$. However, this crumpling is most evident on the left arm of the chromosome. Thus the phenomenon of

\footnotetext{
${ }^{1}$ Program in Systems Biology, Program in Gene Function and Expression, Department of Biochemistry and Molecular Pharmacology, University of Massachusetts Medical School, Worcester MA 01605, USA Full list of author information is available at the end of the article
}

"activation"/"repression" of the left arm of Chr. III which is associated with mating type-specific switching preference is, in fact, associated with a difference in the innate conformation of Chr. Ill between the two mating types. This difference in structure between mating types will be used as a phenotype to analyze the effect of cis and trans acting factors that play a role in switching preference through alteration of chromosome conformation.

\section{Author details}

'Program in Systems Biology, Program in Gene Function and Expression, Department of Biochemistry and Molecular Pharmacology, University of Massachusetts Medical School, Worcester MA 01605, USA. ${ }^{2}$ Structural Genomics Team, CNAG - Centro Nacional de Análisis Genómico and Structural Genomics Group - Gene Regulation, Stem Cells and

Cancer Program - Center for Genomic Regulation (CRG), Barcelona Spain.

${ }^{3}$ LBME - CNRS University of Toulouse, France.

Published: 18 March 2013

doi:10.1186/1756-8935-6-S1-P92

Cite this article as: Belton et al: Mating type specific chromosome conformation in Saccharomyces cerevisiae. Epigenetics \& Chromatin 2013 6(Suppl 1):P92.

Submit your next manuscript to BioMed Central and take full advantage of:

- Convenient online submission

- Thorough peer review

- No space constraints or color figure charges

- Immediate publication on acceptance

- Inclusion in PubMed, CAS, Scopus and Google Scholar

- Research which is freely available for redistribution 